\title{
Onshore dismantling 'the best option' for most oil platforms
}

London \& Munich. Disused oil installations made from large quantities of steel should be dismantled and recycled on land, and not dumped in the sea, according to a report commissioned by the German government.

The report, Regulations for Decommissioning Offshore Platforms in the North Sea and North Atlantic, a summary of which is due to be published in Berlin this week, says that onshore dismantling of steel installations is healthier for the marine environment and cheaper, as 95 per cent of most structures can be recycled for scrap metal.

But the report recommends that concrete structures should be sunk, because they cannot be recycled. Their prohibitive weight - around 1 million tonnes - rules out lifting by cranes or towing with barges. Concrete structures represent 5 per cent of the 400 oil installations in the North Sea; the rest are made from steel.

The findings have been welcomed by the environmentalist group Greenpeace, which last year succeeded in preventing the Shell oil company from dumping Brent Spar, a 14,500-tonne disused steel oil-storage buoy, in the North Sea (see Nature 376, 378; 1995). But they have been rejected as "irrelevant" by Shell, which last week announced a 21-strong list of bids from consortia to decommission the buoy, currently moored off the Norwegian coast.

Shell reversed its original plan following a public outcry, particularly in Germany. Critics opposed the dumping on the controversial - grounds that the structure could harm the deep-sea environment.

The company now says that it can no longer rule out deep-water disposal, as a new structural survey of Brent Spar suggests that the buoy could break up while being towed to land.

But Markus Grosse Ophoff, a scientific adviser to Germany's Federal Environment Agency, which compiled the report, says that oil installations need not be towed in once piece. "Oil installations are built in sections," he says. The engineering capability exists, he adds, to separate the sections offshore before towing them to land.

However, Dave Stuart, a spokesman for Shell, says any attempt to bring Brent Spar on to land will require raising the 137 metre-high structure further out of the water; most of Brent Spar is submerged. The structural survey shows that the walls of Brent Spar's storage tanks have been weakened and might collapse during any attempt to pump water out of the tanks to raise Brent Spar. Stuart reiterates, however, that Shell is not ruling out any option.

\section{Industrial world is unlikely to meet promised carbon cuts}

London. Commitments by most industrialized countries to reduce emissions from fossil fuels to 1990 levels by the end of the decade are unlikely to be met, according to a report published last week by the World Energy Council (WEC), an international body supported by the energy industry.

Global carbon dioxide $\left(\mathrm{CO}_{2}\right)$ emissions from burning fossil fuels rose by 12 per cent in the first half of the current decade, says the report. The largest rise has come from developing countries, whose increase in emissions from fossil-fuel burning has been more than three times the increase for industrialized countries.

But the survey also shows that industrialized countries - with the exception of France, Germany and the United Kingdom - are unlikely to meet the goal of returning $\mathrm{CO}$, emissions to 1990 levels before the start of the next century, as agreed under the United Nations (UN) climate convention signed in Rio de Janeiro three years ago. In contrast, $\mathrm{CO}_{2}$ emissions in eastern Europe and the former Soviet Union have already dropped to below their 1990 levels.

The survey was published to coincide with this week's UN meeting - the second annual conference of the parties to the climate convention - one of whose goals is to negotiate new targets to reduce $\mathrm{CO}_{2}$ emissions beyond 2000 .

The WEC survey shows that between 1990 and 1995, most member countries of the Organization for Economic Cooperation and Development (OECD) registered a 4 per cent rise in $\mathrm{CO}_{2}$ emissions. But countries in the Asia-Pacific region - excluding Australia, New Zealand and Japan - showed a 30 per cent rise. Emissions in countries in the Middle East increased by 35 per cent, in Africa by 12.5 per cent and in Latin America by 8 per cent.

Economic decline contributed to a reduction in $\mathrm{CO}_{2}$ emissions in countries of the former Soviet Union and central and $\mathrm{CO}_{2}$ emissions from fossil fuel combustion

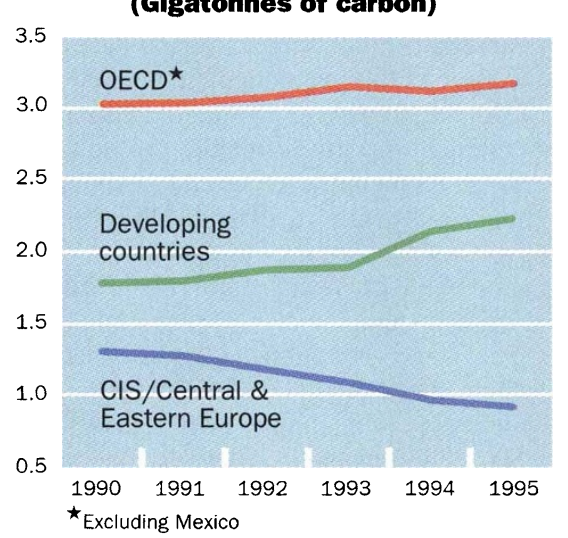

eastern Europe, according to the survey. In 1995, emissions from the Commonwealth of Independent States (CIS) of the former Soviet Union were 70 per cent of their 1990 levels, and 75 per cent for central and eastern Europe. But the combined $\mathrm{CO}_{2}$ emissions for both regions in 1990-95 increased by 3 per cent.

Countries in the developing world are under no obligation to reduce their $\mathrm{CO}_{2}$ emissions, as they are not party to the climate convention. On the basis of the WEC's statistics, future draft agreements on reducing emissions are unlikely to exclude them. However, many developing countries consider cutting back on $\mathrm{CO}$ emissions an unwelcome brake on their drive for industrialization.

"Reducing $\mathrm{CO}_{2}$ emissions because of climate change has placed developing countries in a really serious bind," says Abdul Bar al Gain, director of Saudi Arabia's environment agency, and head of the country's delegation to the UN climate talks.

"It's like telling a poor trader who saved for 20 years to buy a van to carry on making deliveries using his donkey cart. It's not fair. We need to find some other solution for those developing countries that will become increasingly dependent on fossil fuel burning."

Anwar Ibrahim, deputy prime minister of Malaysia, points out that industrialized countries continue to be responsible for more than half of the world's $\mathrm{CO}_{2}$ emissions. But he says that both sides need to be flexible in negotiations on future emissions reductions.

"It is very important not to condemn the West," he says. "Otherwise this will give licence to developing countries to rape their forests and pollute their environment." Carbon dioxide emissions from burning oil in Malaysia increased by 66 per cent between 1990 and 1995 .

Governments are not required under the convention to agree on steps towards further emissions reductions beyond 2000 until the third annual climate-convention conference, due to be held next year. Michael Jefferson, deputy secretary general of the WEC, says that, on the basis of this latest survey, setting firm targets for further reductions would not be realistic at this stage.

But Helen Wallace, a senior scientist with Greenpeace, says the survey will provide a stronger focus for calls to reduce $\mathrm{CO}_{2}$ emissions to 20 per cent of their 1990 levels by 2005. Environmental groups - including Greenpeace - belonging to the Climate Action Network regard the focus on developing countries as "a dangerous and time wasting" digression.

Ehsan Masood 